\title{
Identification and Quantification of Polyphenols from Pineapple Peel by High Performance Liquid Chromatography Analysis
}

\author{
A. S. Lubaina*, P. R. Renjith, A. S Roshni \\ Department of Botany, Christian College, Kattakada, 695572, Thiruvananthapuram, Kerala, India
}

Received April 16, 2020; Revised May 14, 2020; Accepted June 16, 2020

\section{Cite This Paper in the following Citation Styles}

(a): [1] A. S. Lubaina, P. R. Renjith, A. S Roshni, "Identification and Quantification of Polyphenols from Pineapple Peel by High Performance Liquid Chromatography Analysis," Advances in Zoology and Botany, Vol. 8, No. 5, pp. 431 - 438, 2020. DOI: 10.13189/azb.2020.080507.

(b): A. S. Lubaina, P. R. Renjith, A. S Roshni (2020). Identification and Quantification of Polyphenols from Pineapple Peel by High Performance Liquid Chromatography Analysis. Advances in Zoology and Botany, 8(5), 431 - 438. DOI: 10.13189/azb.2020.080507.

Copyright $\subseteq 2020$ by authors, all rights reserved. Authors agree that this article remains permanently open access under the terms of the Creative Commons Attribution License 4.0 International License

Abstract High performance liquid chromatography (HPLC) is an important analytical method applied for the separation and quantification of phenolic constituents. The present study concerned with the characterization of polyphenols from petroleum ether, ethyl acetate, ethanol and water extracts of pineapple peel by HPLC analysis. Due to poor waste management practices, pineapple processing industries produced huge amount of peel usually thrown away as waste creates pollution. Pineapple peel could be a potential source for the extraction of beneficial bioactive phenolic compounds used widely in pharmaceutical industries. The results of this study revealed the presence of 13 different polyphenols in pineapple peel. Among the four extracts evaluated ethyl acetate and ethanol showed maximum number of polyphenols. Apigenin, a natural flavone having significant anti-inflammatory, antioxidant and anti-carcinogenic properties reported firstly from pineapple peel. The quantification of phenolic acids by HPLC analysis of the pineapple peel resulted polyphenol viz. myrecetin $(20.31192 \mu \mathrm{g} / \mathrm{mg})$ in highest amount followed by gallic acid $(15.99272 \mu \mathrm{g} / \mathrm{mg})$ and elagic acid $(10.17904 \mu \mathrm{g} / \mathrm{mg})$. Fractionation and quantification of phenolic constituents by HPLC analysis is a prerequisite for further studies and thereby utilizing this waste and established a waste management program. Further studies are warranted to isolate and purify the lead phenolic constituent from this waste, evaluate the biological potentialities and its application in pharmaceutical industries.

Keywords HPLC, Pineapple Peel, Polyphenols, Apigenin, Myrecetin, Gallic Acid

\section{Introduction}

Pineapple (Ananas comosus (L.) Merr.), a leading edible member of the family Bromeliaceae cultivated widely in the tropical areas of the world. Commercially, it is mainly produced as canned fruits and processed as juice, concentrates and jam. The increasing production of pineapple processed items, results in massive waste generations in the form of peel. Lack of proper waste management measures it is usually dumped as landfills may cause serious environmental problems. Fruit peels are a rich source of polyphenols and their concentration in these fractions is more than twice in edible tissues.

Polyphenols are ubiquitous secondary metabolites reported to possess many biological potentialities such as anticancer, antimicrobial, antihelminthic, antioxidant and wound healing [1]. They are produced in plants from shikimic acid via the phenyl propanoid pathway, as by-products of the monolignol reactions and also as catabolic products of lignin and other cell wall polymers in 
plants. The phenolic acids are polyphenols with common bio-genetic precursor classified into three main groups viz. benzoic acid derivative, hydroxycinnamic acid derivative and depside. The commonest is hydroxycinnamic acid which consists mainly of ferulic, p-coumaric, caffeic, sinapic acid etc. The derivatives of hydroxy benzoic acid include vanillic, protocatechuic, p-hydroxy benzoic acid etc. which are found predominantly as glycosides. These groups are well-known for their analgesic, antipyretic, cholagogic, sedative and anti-biotic properties [2].

The amazing antioxidant cum nutraceutical properties of phenolics attracted global attention over the past decades. The biological activities can only be rationalized by separating and quantitating such compounds [3]. Chromatographic techniques have significant role in the discovery of novel and innovative compounds of pharmaceutical and biomedical importance. The diversity of phenolic compound in plants can be quantified by various analytical methods like gas chromatography, thin-layer chromatography, capillary electrophoresis, HPLC, HPLC-DAD-UV etc. [4].

HPLC offers popular techniques for the separation and quantification of enantiomers because of the progressive improvement in chiral stationary phase of columns. HPLC system equipped with a chiral detector allows determination of the absolute configuration of chiral compounds directly. $\beta$-cyclodextrin is a 7-membered ring of (1-4) linked $\alpha$-glucopyranosyl units whereas amylose and cellulose are the polysaccharides composed of glucose units connected by 1,4- $\alpha$-glucopyranosyl and 1,4- $\beta$-glucopyranosyl linkages respectively. The molecular size and the chemical structure of amylose, cellulose and $\beta$-cyclodextrin are quite different. They can be converted to various derivatives such as acylate, carbamate and phenyl carbamate. Amylose, cellulose, $\beta$-cyclodextrin and phenyl carbamate derivatives have been widely applied to resolve the enantiomers of a large number of racemates by chiral HPLC analysis [5-9]. The combination of these versatile chiral HPLC columns and chiral detectors can be used to analyze many novel enantiomeric compounds [10]. Despite the presence of some classical methods of chiral separation such as preferential crystallization and enzymatic degradation, some advanced techniques have been developed for this purpose including chromatographic, electrophoretic, biosensor and spectroscopic tools. Electrophoretic method for chiral separation includes its various forms like capillary gel electrophoresis, capillary zone electrophoresis and capillary isotachophoresis [11]. On the other hand, chromatographic chiral resolution technique has also received the importance through its liquid chromatographic method. Liquid chromatography covers mainly high-performance liquid chromatography, thin layer chromatography etc. The most important aspect in chiral resolution by high-performance liquid chromatography is the application of chiral stationary phases such as polysaccharides, cyclodextrins, macrocyclic glycopeptide antibiotics, crown ethers, proteins and ligand exchangers [12]. In this juncture the present study targeted to separate and quantify the polyphenol composition from different solvent extracts of pineapple peel using HPLC analysis.

\section{Materials and Methods}

\subsection{Plant Material}

The material used for the study was the peel of Mauritius variety (the most popular cultivar grown in Kerala) of pineapple fruit collected from Pineapple Research Station, Kerala Agriculture University, Vazhakulam, Muvattupuzha, Kerala.

\subsection{Soxhlet Hot Continuous Extraction}

$250 \mathrm{~g}$ pineapple peel were finely chopped, air dried in shade at room temperature, powdered and successively extracted with $100 \mathrm{ml}$ of petroleum ether, ethyl acetate, ethanol and water for eight hours using soxhlet hot continuous extraction method. The extracts were filtered and concentrated using rotary evaporator at $50^{\circ} \mathrm{C}$. The yields of extracts were calculated.

\subsection{High Performance Liquid Chromatography (HPLC)}

The petroleum ether, ethyl acetate, ethanol and water extracts of pineapple peel and 13 reference compounds $(1 \mathrm{mg} / \mathrm{mL})$ were filtered through $0.45 \mu \mathrm{m}$ PTFE filter; $20 \mu \mathrm{L}$ was injected into the HPLC system. The analysis was performed on a prominence UFLC system containing LC-20AD system controller, phenomenex Gemini C18 column $(250 \times 4.6 \mathrm{~mm}, 5 \mu \mathrm{m})$, a column oven (CTO-20A), a Rheodyne injector (USA) with a loop of $20 \mu 1$ volume and a diode array detector (SPD-M20A). The mobile phase used was, solvent A; methanol- acetic acid - water (10:2:88, v/v) and solvent B; methanol - acetic acid - water $(90: 2: 8, \mathrm{v} / \mathrm{v})$ with gradient program $0-15 \mathrm{~min} 15 \% \mathrm{~B}, 16-20 \mathrm{~min} 50 \% \mathrm{~B}$, $21-35 \mathrm{~min} 70 \% \mathrm{~B}, 36-50 \mathrm{~min} 100 \% \mathrm{~B}$ and finally the column was regenerated in $10 \mathrm{~min}$. The injection volume was $20 \mu \mathrm{L}$, and the flow rate was kept at $1 \mathrm{~mL} / \mathrm{min}$. The column was maintained at room temperature and eluted fractions were monitored at $280 \mathrm{~nm}$. Sample peaks were identified by comparing with retention times of standard peaks. LC Lab solution software was used for data acquisition and analysis.

\section{Results and Discussion}

\subsection{High Performance Liquid Chromatography (HPLC) Analysis}

The polyphenol content in the four extracts of pineapple 
peel were estimated using high-performance liquid chromatography. Thirteen standard polyphenolic compounds $(1 \mathrm{mg} / \mathrm{ml})$ were analyzed namely (1) Gallic acid, (2) Catechol, (3) Chlorogenic acid, (4) Caffeic acid (5) Syringic acid, (6) p-coumaric acid, (7) Ferulic acid, (8) Elagic acid, (9) Myercetin, (10) Cinnamic acid, (11) Quercetin, (12) Kaempferol and (13)Apigenin. Their retention time $(\mathrm{Rt})$ were $7.724,12.773,23.807,25.349$, 26.298, 27.567, 28.629, 31.155, 31.814, 33.329, 34.531, 37.586 and 38.322 respectively (Table 1) \& (Fig. 1). Identification and quantification were carried out by comparing the retention time and spectra of sample components with that of standards.

Fractionation of polyphenols in the petroleum ether extract of pineapple peel (Table 2) (Fig. 2) revealed the presence of poly phenols such as gallic acid (0.41048 $\mu \mathrm{g} / \mathrm{mg})$, catechol $(0.042269 \mu \mathrm{g} / \mathrm{mg})$, chlorogenic acid $(0.72014 \mu \mathrm{g} / \mathrm{mg})$, caffeic acid $(0.279394 \mu \mathrm{g} / \mathrm{mg})$, syringic acid (1.162054 $\mu \mathrm{g} / \mathrm{mg})$, p-coumaric acid $(0.01125 \mu \mathrm{g} / \mathrm{mg})$, cinnamic acid $(0.52746 \mu \mathrm{g} / \mathrm{mg})$, quercetin $(0.77613$ $\mu \mathrm{g} / \mathrm{mg})$, kaempferol (4.43208 $\mu \mathrm{g} / \mathrm{mg})$ and apigenin $(0.17197 \mu \mathrm{g} / \mathrm{mg})$ whereas catechol $(0.241165 \mu \mathrm{g} / \mathrm{mg})$, chlorogenic acid $(0.610084 \mu \mathrm{g} / \mathrm{mg})$, caffeic acid $(0.29168$ $\mu \mathrm{g} / \mathrm{mg})$, syringic acid $(9.3286 \mu \mathrm{g} / \mathrm{mg})$, ferulic acid $(1.0235$ $\mu \mathrm{g} / \mathrm{mg})$, elagic acid $(1.79662 \mu \mathrm{g} / \mathrm{mg})$, myricetin $(20.31192$ $\mu \mathrm{g} / \mathrm{mg})$, cinnamic acid $(0.4919 \mu \mathrm{g} / \mathrm{mg})$, quercetin $(3.27957$ $\mu \mathrm{g} / \mathrm{mg})$, kaempferol $(5.5894 \mu \mathrm{g} / \mathrm{mg})$ and apigenin (8.12184 $\mu \mathrm{g} / \mathrm{mg}$ ) were found in the ethyl acetate extract (Table 2) (Fig. 3).

Table 1. The retention time of standard mixture of polyphenols

\begin{tabular}{|c|c|c|}
\hline Sl. No & Polyphenols & Retention Time \\
\hline 1 & Gallic Acid & 7.724 \\
\hline 2 & Catechol & 12.773 \\
\hline 3 & Chlorogenic Acid & 23.807 \\
\hline 4 & Caffeic Acid & 25.349 \\
\hline 5 & Syringic Acid & 26.298 \\
\hline 6 & p-Coumaric Acid & 27.924 \\
\hline 7 & Ferulic Acid & 28.629 \\
\hline 8 & Elagic Acid & 31.155 \\
\hline 9 & Myricetin & 31.181 \\
\hline 10 & Cinnamic Acid & 33.329 \\
\hline 11 & Quercetin & 34.531 \\
\hline 12 & Kaempferol & 37.586 \\
\hline 13 & Apigenin & 38.322 \\
\hline
\end{tabular}

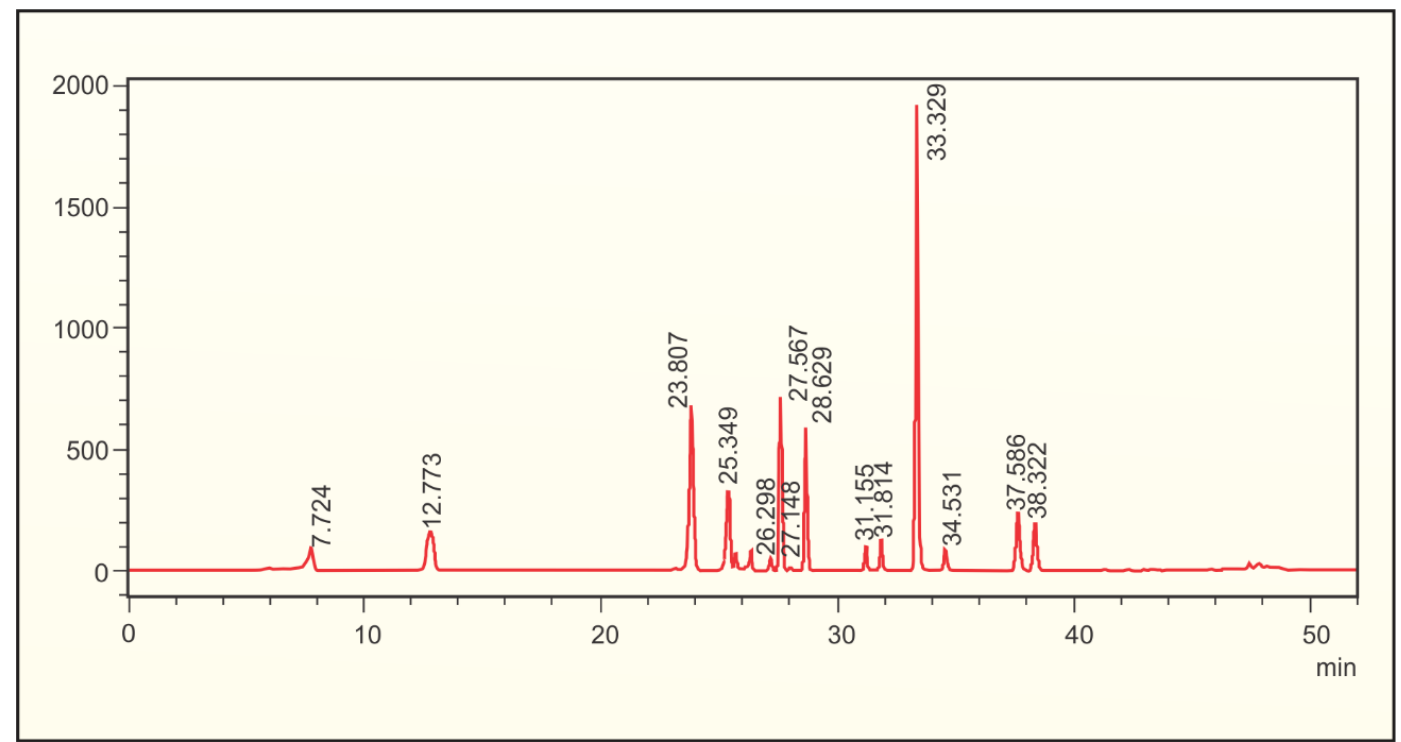

Figure 1. HPLC chromatogram of standard mixture of polyphenols consists of Gallic acid (7.724), Catechol (12.77), Chlorogenic acid (23.807), Caffeic acid (25.34), Syringic acid (26.298), p-coumaric acid (27.567), Ferulic acid (28.629), Elagic acid (31.155), Myercetin (31.1814), Cinnamic acid (33.329), Quercetin (34.531), Kaempferol (37.586), Apigenin (38.322) with retention time (Rt) 
Table 2. Quantification of polyphenols in four samples (1,2,3 \&4 are petroleum ether, ethyl acetate, ethanol and aqueous extracts respectively) of pineapple peel by HPLC analysis

\begin{tabular}{|c|c|c|c|c|c|c|c|c|c|c|c|c|c|}
\hline Samples & $\begin{array}{c}\text { Gallic acid } \\
(\mu \mathrm{g} / \mathrm{mg})\end{array}$ & $\begin{array}{c}\text { Catechol } \\
(\mu \mathrm{g} / \mathrm{mg})\end{array}$ & $\begin{array}{c}\text { Chlorogenic } \\
\text { acid } \\
(\mu \mathrm{g} / \mathrm{mg})\end{array}$ & $\begin{array}{c}\text { Caffeic } \\
\text { Acid } \\
(\mu \mathrm{g} / \mathrm{mg})\end{array}$ & $\begin{array}{c}\text { Syringic } \\
\text { acid } \\
(\mu \mathrm{g} / \mathrm{mg})\end{array}$ & $\begin{array}{c}\text { p-coumaric } \\
\text { acid } \\
(\mu \mathrm{g} / \mathrm{mg})\end{array}$ & $\begin{array}{c}\begin{array}{c}\text { Ferulic } \\
\text { acid } \\
(\mu \mathrm{g} / \mathrm{mg})\end{array} \\
\end{array}$ & $\begin{array}{c}\begin{array}{c}\text { Elagic } \\
\text { acid } \\
(\mu \mathrm{g} / \mathrm{mg})\end{array} \\
\end{array}$ & $\begin{array}{l}\text { Myrecetin } \\
(\mu \mathrm{g} / \mathrm{mg})\end{array}$ & $\begin{array}{c}\text { Cinnami } \\
\text { c acid } \\
(\mu \mathrm{g} / \mathrm{mg})\end{array}$ & $\begin{array}{l}\text { Quercetin } \\
(\mu \mathrm{g} / \mathrm{mg})\end{array}$ & $\begin{array}{c}\text { Kaempferol } \\
(\mu \mathrm{g} / \mathrm{mg})\end{array}$ & $\begin{array}{c}\text { Apigenin } \\
(\mu \mathrm{g} / \mathrm{mg})\end{array}$ \\
\hline 1 & 0.41048 & 0.042269 & 0.72014 & 0.279394 & 1.162054 & 0.01125 & 0 & 0 & 0 & 0.52746 & 0.77613 & 4.43208 & 0.17197 \\
\hline 2 & 0 & 0.241165 & 0.610084 & 0.29168 & 9.3286 & 0 & 1.0235 & 1.79662 & 20.31192 & 0.4919 & 3.27957 & 5.58948 & 8.12184 \\
\hline 3 & 0.147668 & 0.025955 & 0 & 0.068856 & 1.0048 & 0.53376 & 0.15888 & 1.82858 & 0.00343 & 0.22905 & 4.18332 & 4.43504 & 4.9092 \\
\hline 4 & 15.99272 & 0 & 0.03489 & 0 & 0.00718 & 1.61278 & 0.19647 & 10.17904 & 0 & 2.14584 & 5.08665 & 2.50604 & 1.50138 \\
\hline
\end{tabular}

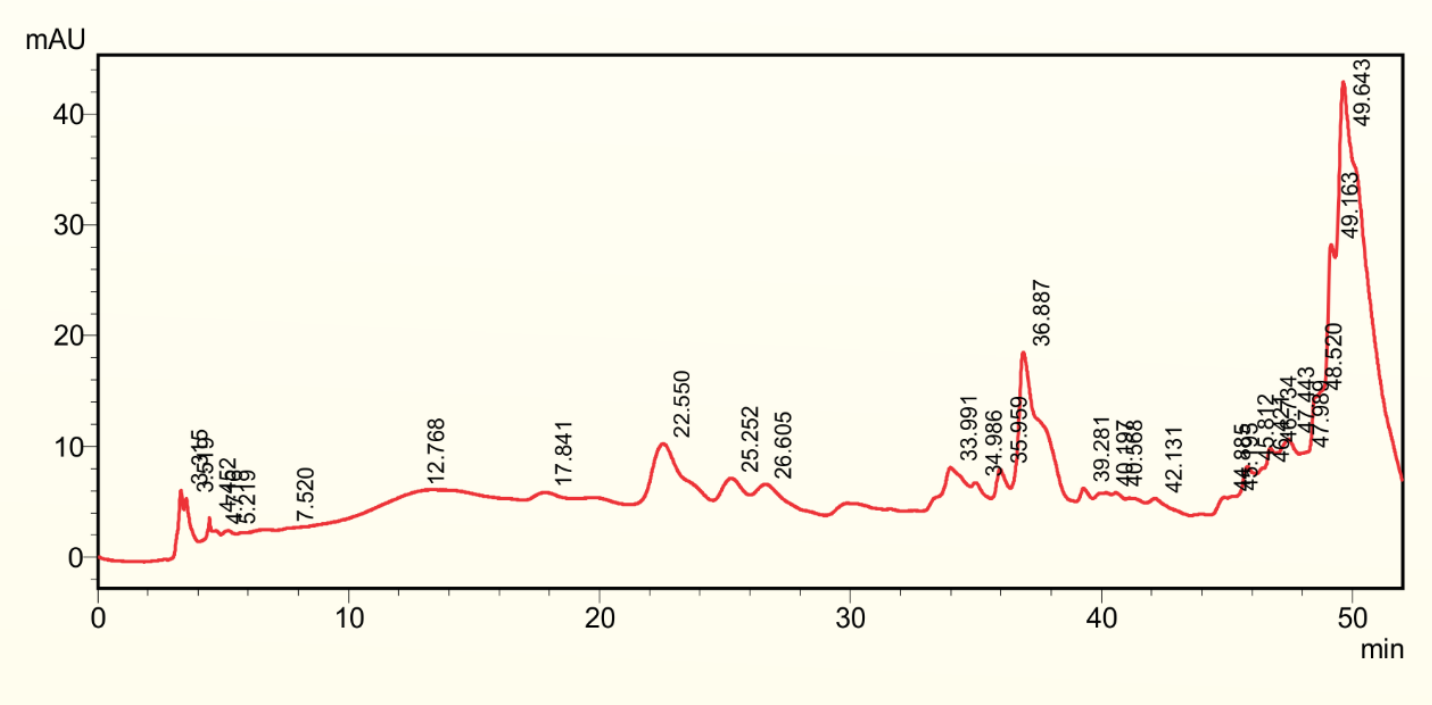

Figure 2. HPLC Chromatogram of petroleum ether extract 


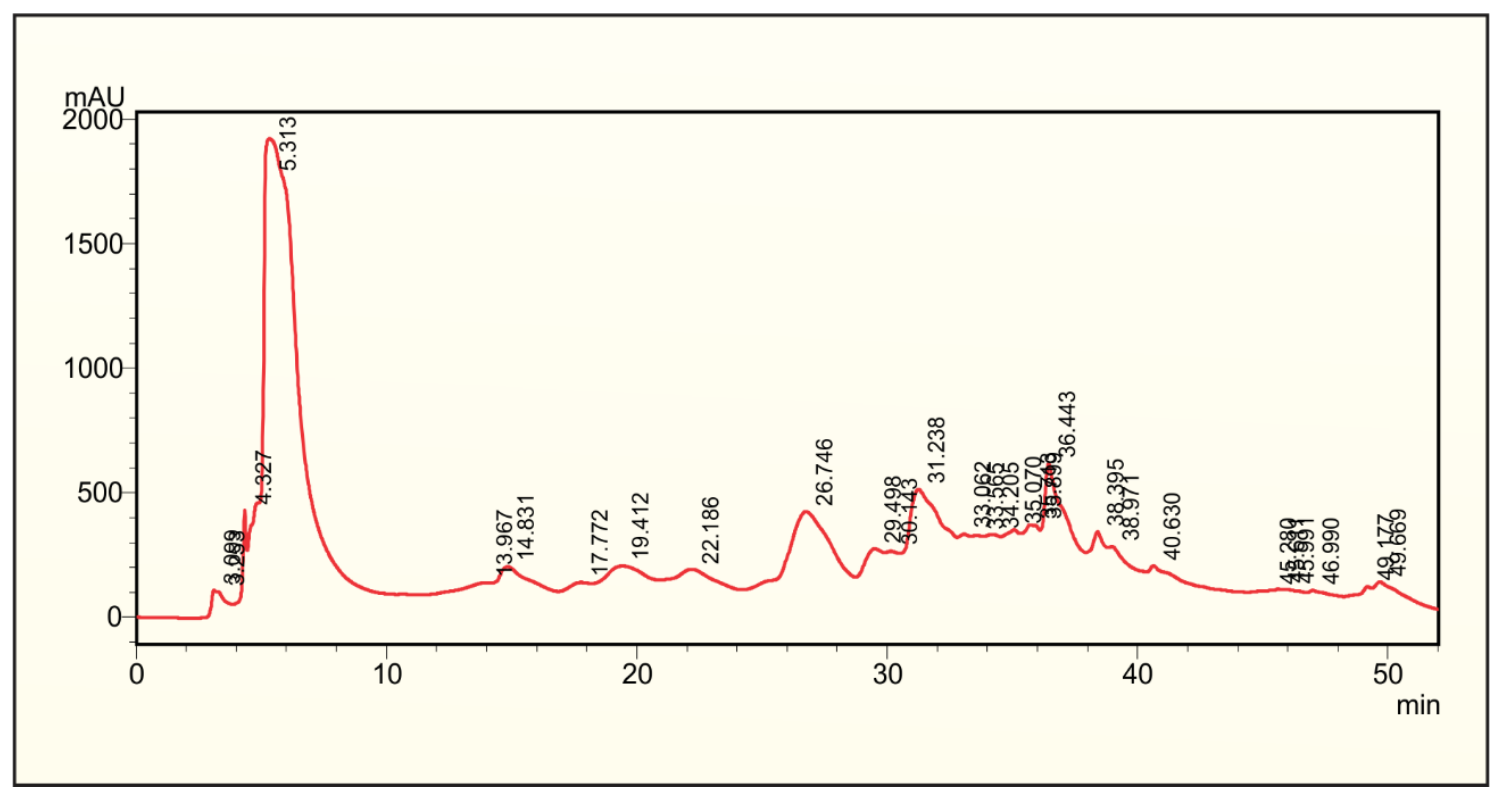

Figure 3. HPLC Chromatogram of ethyl acetate extract

Polyphenol profiling of the ethanol extract resulted gallic acid $(0.147668 \mu \mathrm{g} / \mathrm{mg})$, catechol $(0.025955 \mu \mathrm{g} / \mathrm{mg})$, caffeic acid $(0.068856 \mu \mathrm{g} / \mathrm{mg})$, syringic acid $(1.0048 \mu \mathrm{g} / \mathrm{mg}), p$-coumaric acid $(0.53376 \mu \mathrm{g} / \mathrm{mg})$, ferulic acid $(0.15888 \mu \mathrm{g} / \mathrm{mg})$, elagic acid $(1.82858 \mu \mathrm{g} / \mathrm{mg})$, myricetin $(0.00343 \mu \mathrm{g} / \mathrm{mg})$, cinnamic acid $(0.22905 \mu \mathrm{g} / \mathrm{mg})$, quercetin $(4.18332 \mu \mathrm{g} / \mathrm{mg})$, kaempferol (4.43504 $\mu \mathrm{g} / \mathrm{mg}$ ) and apigenin $(4.9092 \mu \mathrm{g} / \mathrm{mg}$ ) (Table 2) (Fig. 4). The water extract showed gallic acid $(15.99272 \mu \mathrm{g} / \mathrm{mg})$, chlorogenic acid $(0.03489 \mu \mathrm{g} / \mathrm{mg})$, syringic acid $(0.00718 \mu \mathrm{g} / \mathrm{mg})$, p-coumaric acid $(1.61278 \mu \mathrm{g} / \mathrm{mg})$, ferulic acid $(0.19647 \mu \mathrm{g} / \mathrm{mg})$, elagic acid $(10.17904 \mu \mathrm{g} / \mathrm{mg})$, cinnamic acid $(2.14584 \mu \mathrm{g} / \mathrm{mg})$, quercetin $(5.08665 \mu \mathrm{g} / \mathrm{mg})$, kaempferol (2.50604 $\mu \mathrm{g} / \mathrm{mg}$ ) and apigenin (1.50138 $\mu \mathrm{g} / \mathrm{mg})$ (Table 2) (Fig. 5)

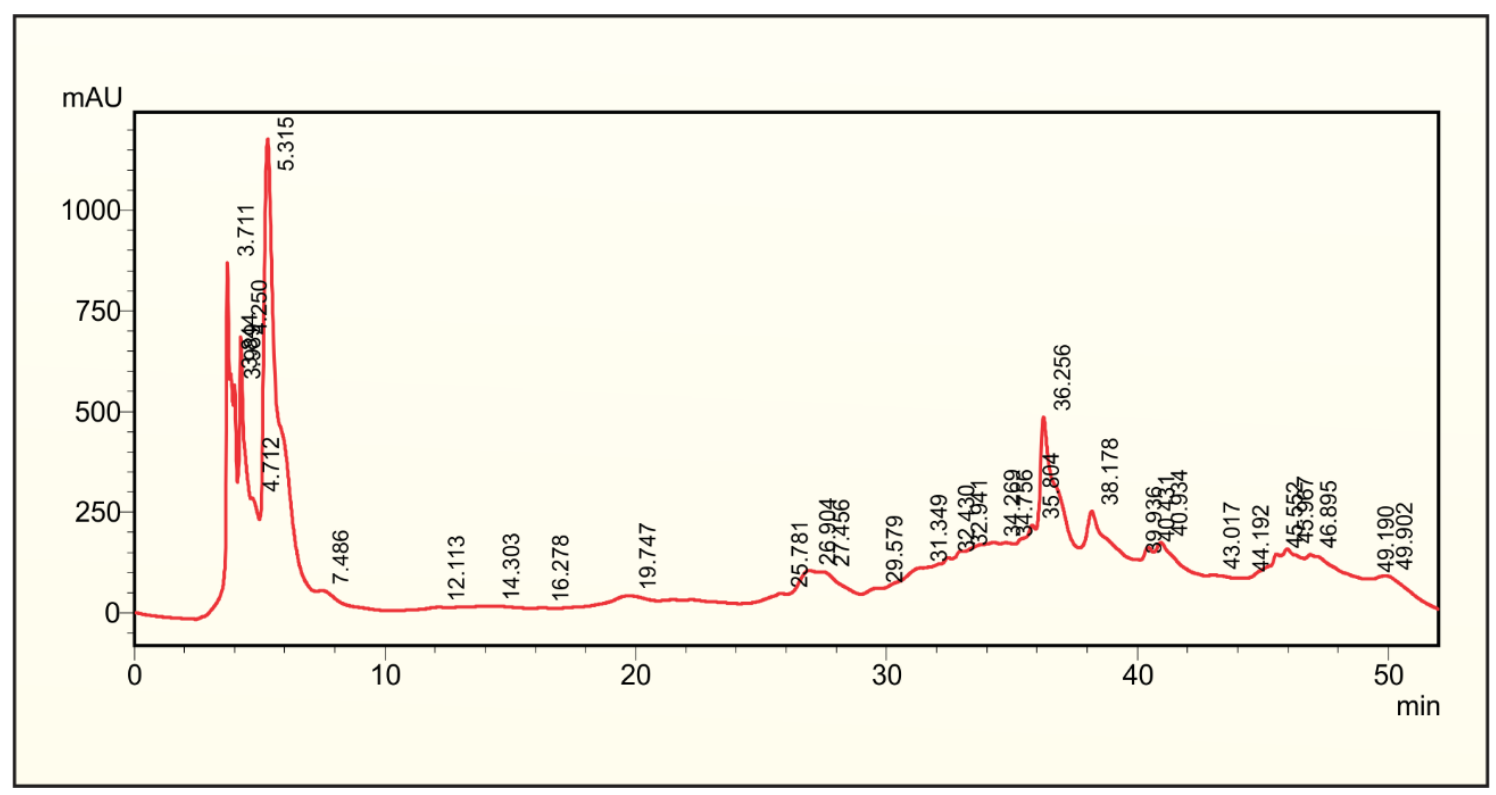

Figure 4. HPLC Chromatogram of ethanol extract 


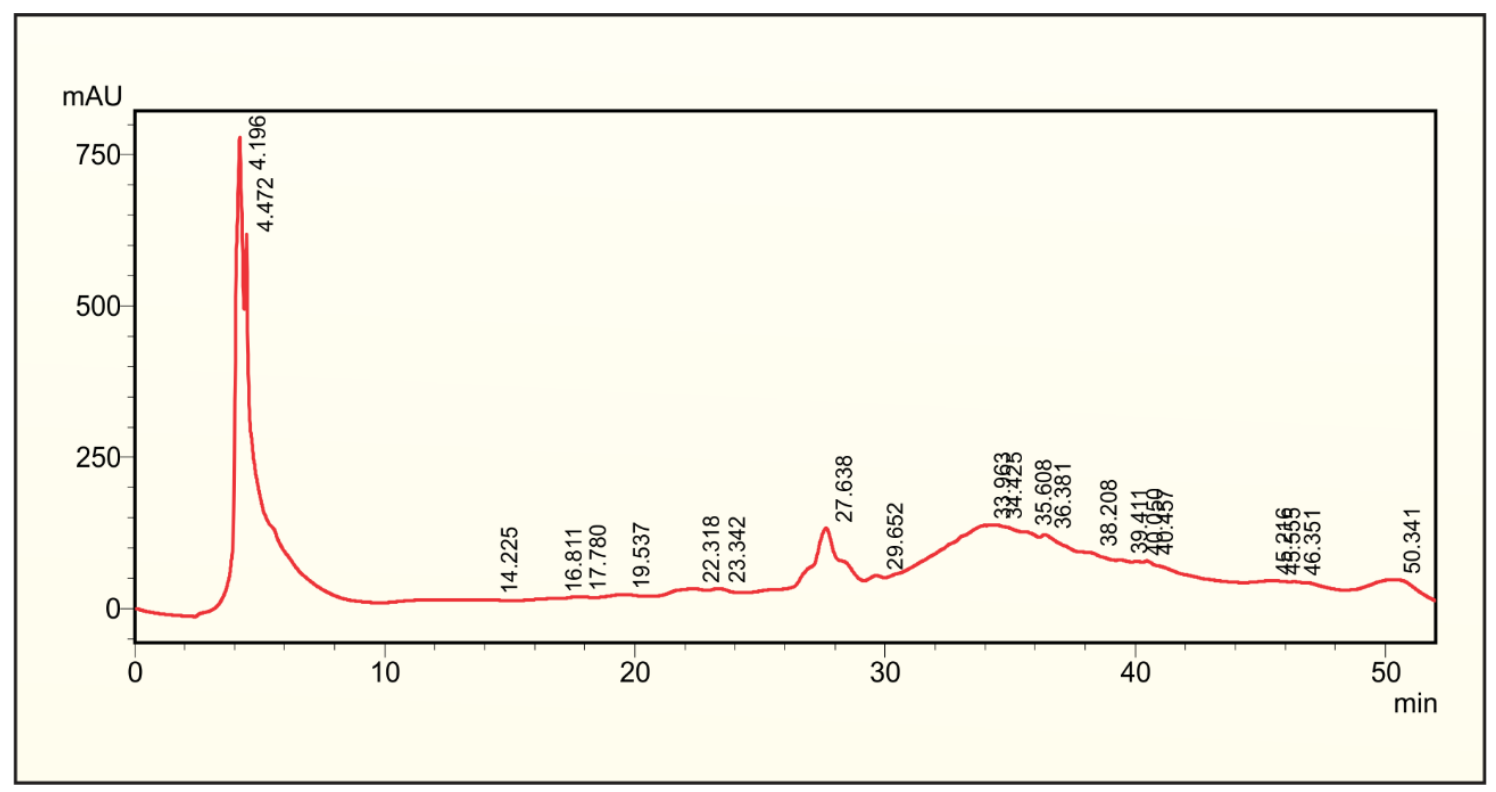

Figure 5. HPLC Chromatogram of water extract

Among the four extracts of pineapple peel ethyl acetate and ethanol showed maximum number of polyphenols. Gallic acid is a powerful antioxidant found in highest quantity in the water extract $(15.99272 \mu \mathrm{g} / \mathrm{mg})$. Catechol a common building block in organic synthesis also present in this waste. Chlorogenic acid can regenerate the oxidized vitamin E via caffeate and acts as a pro-oxidant in the propagation phase of LDL oxidation. Caffeic acid a well-known antioxidant which boosts immunity and controls lipid levels in blood showed its presence in three extract of pineapple peel (Table 2).

Flavonoids are phenolic compounds isolated from plants and are valuable for their immense biological potentialities. Apigenin, a natural flavone reported for the first time from pineapple peel having significant anti-inflammatory, antioxidant, antimicrobial and anti-carcinogenic properties. Apigenin was observed to suppress various human cancers in vitro and in vivo by multiple biological effects such as inducing cell cycle arrest, triggering cell apoptosis and autophagy, invasion and suppressing cell migration and stimulating immune response. A flavonoid namely quercetin found in low concentration in the petroleum ether extract displayed anti-histamine, anti-cancer and anti-inflammatory activities. Some glycosides of quercetin have also been found to reduce serum levels of low-density lipoproteins (LDL) and increase high-density lipoproteins (HDL) in addition to the reduction of triglycerides and free fatty acids, contributing to its cardiovascular disease prevention attributes [13].

Another polyphenol namely myricetin found in highest quantity $(20.31192 \mu \mathrm{g} / \mathrm{mg})$ in the ethyl acetate extract. Myricetin is known to interact with a range of DNA and RNA polymerases, reverse transcriptases, telomerases, kinases and helicases due to its iron-chelating, antioxidant, anti-inflammatory and anti-carcinogenic properties.
Reverse transcriptase inhibition activities also implicate it as a possible antiviral drug against Rauscher murine Leukemia Virus (RLV) and Human Immunodeficiency Virus (HIV) infections [14]. It is also a minor flavonol found in field-grown fruits in turn protect them from a wide range of environmental conditions, including temperature, soil, light levels, nutritional conditions and pathogen attack [15]. Syringic acid is well known for its anti-cancer, anti-proliferative, sedative, decongestant and hepato-protective actions. Cinnamic acid has antibacterial, antifungal and anti-parasitic properties. Hydroxycinnamic acid and p-coumaric acid are well documented for its antioxidant behavior reducing the formation of carcinogenic nitrosamines in the stomach [16].

Ferulic acid is well-known for its physiological functions such as anti-microbial, anti-inflammatory and anti-cancer activities. It lowers cholesterol level in serum and increases sperm viability. The HPLC analyses of the pineapple peel revealed the presence of ferulic acid in three extracts, among them ethyl acetate extract showed highest amount $(1.0235 \mu \mathrm{g} / \mathrm{mg})$. Ferulic acid reacts as a natural protector against ultra-violet radiation known to cause skin cancer. Among the natural polyphenols, kaempferol - a flavonol found in many edible plants reported to possess potent pharmacological and nutraceutical activities. The consumption of plants containing kaempferol thereby conferring innumerable health benefits in the form of reducing scourge of cardio vascular diseases, cancer, arteriosclerosis etc. The antioxidant properties are also known to be responsible for these health benefits [17] Kaempferol also modulate crucial component in cellular signal transduction pathways associated with apoptosis, angiogenesis, metastasis and inflammation [18]. The present work showed the presence of high kaempferol content in the ethyl acetate $(5.58948 \mu \mathrm{g} / \mathrm{mg})$ and ethanol 
extract $(4.43504 \mu \mathrm{g} / \mathrm{mg})$ of pineapple peel. The ethyl acetate and ethanol extracts of pineapple peel found to be the optimum solvent of choice as it contains the maximum number of bioactive components in turn supports the biological potentiality of pineapple peel.

A positive correlation was observed between the phenolic acids and total phenols in plants suggesting their role as precursors of many of the secondary metabolites. Flavonoids and phenolic acids possess high biological and pharmacological activities. Gallic acid helps to strengthen veins and to inhibit the formation of amyloid fibrils-the principal causes of Alzheimer's diseases [19]. Phenolic acids namely caffeic acids, not only associate with health benefits, but also extend shelf life by avoiding oxidative deterioration of food and by helping to maintain food colors, flavors and nutritional values. Thus, such natural compounds are useful in pharmaceutics as well as in food industries [20].

\section{Conclusions}

The HPLC fingerprints of the standard phenolic compounds and from the four different extracts of pineapple peel confirmed the presence of different polyphenols having immense pharmaceutical properties, and these results would serve as established benchmarks for future research in this waste. The quantitative analysis of the actual phenolic compounds present in these four samples would be facilitated by means of comparison with standard chromatograms, enabling identification and confirmation of phenolic compounds. By using modern tools these compounds can be isolated from this waste and screened for their biological potentialities.

\section{Acknowledgement}

This work was supported by the Kerala State Council for Science Technology and Environment, Thiruvananthapuram, Kerala (Order No. 355/2018/KSCSTE Dated 14-08-2018).

\section{REFERENCES}

[1] Dilipkumar Pal, Pragya Mishra, NeetuSachan, K. Ashoke. Ghosh. Biological activities and medicinal properties of Cajanus cajan (L) Millsp, Journal of Advanced Pharmaceutical Technological and Research, 2: 207-214, 2011.

[2] M. Waksmundzka-Hajnos, A. Oniszczuk, K. Szewczyk, D. Wianowska. Effect of sample preparation methods on the HPLC quantitation of some phenolic acids in plant materials, Acta Chromatographica, 19: 227-37, 2007.
[3] P. Mattila, J. Hellstrom. Phenolic acids in potatoes, vegetables, and some of their products, Journal of Food Composition and Analysis, 20:152-60, 2007.

[4] A. Arceusz, M. Wesolowski, P. Konieczynski. Methods for extraction and determination of phenolic acids in medicinal plants: a review, Natural Product Communications, 8: 1821-1829, 2013.

[5] H. Y. Aboul-Enein, I. Ali. Determination of tadalafil in pharmaceutical preparation by HPLC using monolithic silica column, Talanta, 65:276-228, 2004.

[6] I. Ali, V. D. Gaitonde, H. Y. Aboul-Enein, et al. Chiral separation of $\beta$-adrenergic blockers on cellucoat column by HPLC, Talanta, 78:458-463, 2009.

[7] I. Ali, V. K. Gupta, H. Y. Aboul-Enein, et al. Role of racemization in optically active drug development, Chirality, 19:453-463, 2007.

[8] H. Y. Aboul-Enein, I. Ali. A comparative study of the enantiomeric resolution of econazole, miconazole and sulconazole by HPLC on various cellulose chiral columns in normal phase mode, Journal of Pharmaceutical and Biomedical Analysis, 27: 441-446, 2002.

[9] I. Ali, H. Y. Aboul-Enein. Enantioseparation of some clinically used drugs by HPLC using cellulose tris- (3,5dichlorophenylcarbamate) chiral stationary phase, Biomedical Chromatography, 17: 113-117, 2003.

[10] I. Ali, H. Y. Aboul-Enein. Impact of immobilized polysaccharide chiral stationary phases on enantiomeric separations, Journal of Separation Science, 29: 762-769, 2006.

[11] I. Ali, M. M. Sanagi, H. Y. Aboul-Enein. Advances in chiral separations by non-aqueous capillary electrophoresis in pharmaceutical and biomedical analysis, Electrophoresis, 35: 926-936, 2014.

[12] H. Y. Aboul-Enein, I. Ali. Chiral separation by liquid chromatography and related technologies. New York, NY: Marcel Dekker Publications, 2003.

[13] S. Nabavi, G. Russo, M. Daglia, S. Nabavi. Role of quercetin as an alternative for obesity treatment: You are what you eat!, Food Chemistry, 179: 305-310, 2015.

[14] D. Semwal, R. Semwal, S. Combrinck, A. Viljoen. A Dietary Molecule with Diverse Biological Activities, Nutrients, 8: 90, 2016.

[15] M. E. J. Crozier, M. S. Lean, McDonald, C. Black. Quantitative analysis of the flavonoid content of commercial tomatoes, onions, lettuce, and celery, Journal of Agricultural and Food Chemistry, 45: 590-595, 1997.

[16] R. Vinayagam. Preventive effect of Syringic acid on hepatic marker enzymes and lipid profile against acetaminophen-induced hepatotoxicity rats, International Journal of Pharmaceutical \& Biological Archives, 1: 393-398, 2010.

[17] A. Mohammad, K. K. Elham. Medicinal uses and chemistry of flavonoid contents of some common edible tropical plants, Journal of Paramedical Sciences, 4: 119-138, 2013.

[18] C. Saw, Y. Guo, A. Yang, X. Paredes-Gonzalez, C. Ramirez, D. Pung, Kong, T. Ah-Ng. The berry constituents quercetin, 
kaempferol, and pterostilbene synergistically attenuate reactive oxygen species: Involvement of the Nrf2-ARE signaling pathway, Food Chemistry and Toxicology, 72: 303-311, 2013.

[19] A. Singh, R. Gupta, R. Pandey. Exogenous application of rutin and gallic acid regulate antioxidants and alleviate reactive oxygen generation in Oryza sativa L., Physiology and Molecular Biology of Plants, 23: 301-309, 2017.

[20] M. Ayoub, A. C. Camargo, F. Shahidi. Antioxidants and bioactivities of free, esterified and insoluble-bound phenolics from berry seed meals, Food Chemistry, 197: 221-232, 2016 